InOedia $\quad \begin{aligned} & \text { InMedia } \\ & \text { The French Journal of Media Studies }\end{aligned}$

5 | 2014

Media and Diversity

Mediating Migration: New Roles for (Mass) Media

Kira Kosnick

(2) OpenEdition

Journals

Electronic version

URL: http://journals.openedition.org/inmedia/761

DOI: 10.4000/inmedia.761

ISSN: 2259-4728

Publisher

Center for Research on the English-Speaking World (CREW)

Electronic reference

Kira Kosnick, « Mediating Migration: New Roles for (Mass) Media », InMedia [Online], 5 | 2014, Online since 17 October 2014, connection on 08 September 2020. URL : http://journals.openedition.org/ inmedia/761; DOI : https://doi.org/10.4000/inmedia.761

This text was automatically generated on 8 September 2020

(c) InMedia 


\title{
Mediating Migration: New Roles for (Mass) Media
}

\author{
Kira Kosnick
}

1 The great bulk of the existing literature on media and migration addresses their intersection mainly in terms of representational issues in the context of mass-mediated communication. Much of it focuses on the representation of migration and migrants in "classical" Western mass media such as television and radio, or popular genres such as film, investigating the use of stereotypical images and narratives. Works such as the much-quoted Unthinking Eurocentrism: Multiculturalism and the Media by Ella Shohat and Robert Stam (1994) developed sophisticated critiques of how migrants as well as racialized and/or ethnic minorities were in such contexts imagined and constructed as "Other" through forms of mass-media representation. A more recent literature has begun to address the production of media representations by migrants themselves, and has thus moved from studying migrants as passive, powerless objects of representation toward investigating their own representational practices and aims. ${ }^{1}$ Discussions of intersectional aspects have been a consistent feature particularly in the first body of literature, where the gendering and racialization of representations has been analyzed as forming part of depicting the influx of migrants as a threat to the body politic of the receiving nation. Both bodies of literature have generated important insights regarding struggles over the representation of migrant minorities and interlinked cultural politics.

2 However, the development and theorization of new media technologies has challenged main paradigms of older mass-media theory, such as the sender-receiver divide and the deployment of mass media in the interest of shaping public opinion. New technologies and forms of convergence between different, formerly distinct media platforms and purposes have transformed not just the social lifeworlds of media "consumers", they have also brought about (as they have been brought about by) new media industries and regulatory frameworks as well as institutions that restrict as well as enable new media uses. ${ }^{2}$ Thus, information technologies fuel contemporary economies of signs and space, ${ }^{3}$ or as Manuel Castells (1993) has put it, the "information 
age", with its complex developments including e-business and forms of e-government, up to ambient intelligence in home environments and ubiquitous computing applications that are increasingly becoming part of everyday life routines for the privileged parts of the globe's population. ${ }^{4}$ Taking note of these developments, it has become increasingly problematic to limit the concept of media to the sender-receiver models of content transmission that dominated common-sense as well as scientific understandings in highly industrialized countries over the course of the 20th century. With regard to the study of media and migration, another emerging body of literature is therefore turning attention to migrants' use of new media technologies for purposes of interpersonal communication and the maintenance of relationships. ${ }^{5}$

This essay focuses on yet other emergent uses of media in relation to migration that have so far received little academic attention: media deployments for the purposes of preventing, stopping but also more generally regulating cross-border migration and mobility, through old and new communication technologies but also through media technologies that are aimed at surveillance, identification and authentication. All of these uses, it will be argued, importantly shape contemporary migration regimes and the ability of migrants and those who facilitate their mobility to negotiate them. What is required for a consideration of some of these uses is a reconceptualization of the concept of media, in order to free it from its common-sense implications of communication technologies and "content" circulated for the purpose of communication as texts, images and sound. It is such an understanding that by and large dominates the literature on media and migration. Yet, if we think of media instead in a wider sense as sign technologies that allow individuals and organizations to construct, filter, store and transmit representations of mobile bodies beyond mass communicative purposes, quite different media practices, infrastructures and informational/representational interests around migration can become visible, as will be shown in the second part of this essay.

4 In the field of media and migration, I therefore suggest looking beyond what has been described above as the "standard fare" of dominant research interests and turning attention to several recent developments of media deployment in the interest of regulating migration. The first examples continue in a sense the "classical" concerns of media and migration research in that they discuss mass-media production intended to communicate particular "messages" concerning the dangers of migratory flows to particular audiences. However, the target audiences of these messages are not so much the lawful residents and citizens of destination countries but rather those deemed at risk of embarking on migration projects in transit countries and countries of origin. Both governments and non-governmental organizations (NGOs) acting on their behalf have started to use mass media to reach out to potential migrant audiences and discourage them from embarking on their journey. Media representations have thus become a factor with which to directly intervene in migration flows, by providing particular and often gendered narratives of danger and tragic failure with regard to border crossings, and by purporting to depict the harsh realities that await undocumented migrants in their destination country.

While such governmental initiatives have attracted some attention - not just among their primary intended target audiences, but also in mass-media reporting reaching audiences in "destination countries" - other, much more consequential uses of media technologies for the regulation of migratory movements across borders have thus far 
received even less critical attention among migration studies scholars. These forms of media use have to do not so much with the communicative politics of representation intended to influence minds, but rather with the informative politics of representation meant to gather data that can unambiguously establish the identity of border-crossing individuals and assess their level of desirability, legitimacy or "threat". The contemporary policing of borders increasingly relies upon information technologies that mediate representations of bodies in order to build up databases and produce individual profiles used to manage the cross-border flow of people. Such uses of media are becoming more ubiquitous, forming part of both commercial and governance strategies of managing bodies and populations at the beginning of the 21st century, as will be discussed below.

\section{European Border Politics}

6 William Walters wrote a few years ago of the need to "denaturalize" our understanding of borders, especially when it comes to understanding European border regimes. ${ }^{6} \mathrm{He}$ and others have highlighted the aspect of "exterritorialization" when it comes to new border-control politics supported by the EU. Regulating migration flows is increasingly seen as a task that involves intervention beyond the actual territory of the $\mathrm{EU}$, increasingly in cooperation with third-country governments and a proliferating NGO sector. ${ }^{7}$ EU countries increasingly seek to stop undesired migrants even before they reach the territorial boundaries of the European Union. Holding airlines and other transport operators responsible for carrying passengers without adequate visas has led to a partial privatization of border control, with migrants potentially being refused transport even before they face immigration officials. ${ }^{8}$ Treaties and cooperation agreements with third countries such as Libya and Turkey are intended to act as another barrier to reaching the territorial borders of the European Union, encouraging non-EU governments to stop migrants crossing their territories on their way to Europe.

Helmut Dietrich (2005) has thus spoken of the Mediterranean region as a new area of determent, one in which countries such as Italy, Spain and France cooperate with North African countries in the patrolling of passageways across the Mediterranean Sea, in which EU ministers debate the creation and financing of camps to deal with potential asylum seekers outside EU territory, and in which North African countries receive European aid to build up population databases in order to single out unwanted migrants, but also to arrest and deport them. ${ }^{9}$ Forcing or paying third countries such as Libya to arrest and deport migrants allows EU governments in the worst-case scenario to pay lip service to humanitarian principles, while the inhumane treatment of migrants is rendered invisible or externalized as the regrettable practice of a nonEuropean state. ${ }^{10}$

8 The horrible fate of many who unsuccessfully try to cross Mediterranean borders into the European Union has been publicized in EU mass media, yet this reporting has rarely been coupled with a critique of the policies that have forced migrants to take ever greater risks in order to reach European territories. While the numerical majority of undocumented migrants in the $\mathrm{EU}$ is estimated to consist of people who have overstayed their visas, and has thus crossed borders "legally", media attention is overwhelmingly focused on those who embark on increasingly dangerous journeys via the sea or transcontinental transport routes, in danger of suffocating in trucks or being 
washed up against the beaches of Lampedusa or the Canary Islands. Metaphors and imagery of "being swamped" have formed part of European mainstream media reporting ever since the refugee crisis was identified as a "threat" to European integration. ${ }^{11}$ Reporting with a humanitarian bent tends to present the manifold human tragedies unfolding in European border regions as the result of desperation coupled with recklessness: why would anyone risk death, braving the Mediterranean Sea crammed into a small fishing boat without life vests and adequate provisions, or trust unscrupulous traffickers interested in nothing but financial gain? The upshot of such reporting is that people had better not embarked on their journey to begin with. Even a critically acclaimed film such as Michael Winterbottom's In This World (2003), with its raw documentary style, leaves its audience more than wondering if its protagonists' trials and tribulations in reaching London have been worth it. This is indeed the message that much state-sponsored media reporting on "illegal" migration is similarly trying to get across - not just to European audiences, but to potential migrants themselves.

\section{Hearts and Minds}

9 In the past few years, governments and related agencies in Europe and the United States have developed new strategies to prevent potential migrants from trying to leave their places of origin in the first place. This is a "hearts and minds" approach in the sense that it forms part of a repertoire of new border-control measures that have direct communicative dimensions. State-funded media campaigns aiming to deter potential migrants in their countries of origin are proliferating, often with the help of NGOs. Céline Nieuwenhuys and Antoine Pécoud have reported a wide range of efforts by the International Organization for Migration (IOM) to employ deterrence "information" campaigns in parts of Central and Eastern Europe, Southeast Asia and Central America. ${ }^{12}$

10 The point of such campaigns is to convince potential migrants that it is better not to embark on the journey, as attempted in a television campaign that the Spanish government launched in Senegal in 2007. The TV campaign showed drastic images of washed-up male corpses along Spanish beaches, and a tearful African mother and father mourning the death of their sons, full of remorse for not having deterred their children from embarking on the journey. The famous Senegalese singer Youssou N'Dour lent his voice to the campaign, telling potential migrants that they are "the future of Africa" and pleading with them not to leave. ${ }^{13}$ Apart from TV ads, the Spanish government and IOM simultaneously started a broad campaign advertised in print magazines and on public buses in Senegal. Images on buses showed for example a young man holding a small child against the backdrop of the Senegalese flag, with a text below stating "it makes no sense". Images largely focused on the grief of family members left behind and the intergenerational impact of young men leaving the continent. ${ }^{14}$

11 Pictures in print magazines were of a more drastic nature, using images of capsized boats and dead bodies to illustrate the likely fate of those embarking on the journey across the Mediterranean Sea: "Don't risk your life for nothing - you are the future of Africa." Those who embark on the dangerous journey are likely to face death, the images announced, but the underlying narrative amounted to more than that. The 
dangers involved appear as naturally given: while the risk of death during the boat passage across the Mediterranean Sea has increased due to migrants having to resort to increasingly long routes in order to evade detection and forced return by border police and other state agents, the risk of death is attributed solely to the dangers of the sea and the ill-preparedness of migrants who enter overcrowded boats. The factors that propel Africans to risk their lives in order to seek a better future in Europe are not mentioned at all.

Yet, the very image of the capsized and wrecked fishing boats that have lost their human cargo might evoke different associations among the poor in states along the shores of African coastlines. The boats that are now used to carry migrants across the sea to European shores once provided local West African fishing industries with their livelihood, before the sale of fishing rights to industries in Europe and Asia. Experts speak of a severe overexploitation of African resources, leaving local fishing economies struggling and depriving African populations of valuable sources of nutrition. ${ }^{15}$ The European Union has a direct impact on local economies in many African countries that are countries of emigration. The fishing industry is just one example among many that can be mobilized to show how Western and Asian commercial interests but also structural adjustment programmes enforced by the International Monetary Fund (IMF) and the World Bank are negatively affecting the livelihoods of local African populations. Seen in this light, telling young people that they are the future of Africa has a cynical ring to it, even when using a famous African musician to get out the message.

The United States border patrol agency has embarked on a similar strategy of migration deterrence, targeting its campaigns mainly at Mexico but also US cities with large populations of Mexican immigrants. The campaign entitled "No more crosses" is playing on the double meaning of the term: no more border crossings, and no more deaths resulting in crosses as seen in the graveyards shown on posters and video clips posted online ${ }^{16}$. Attempts to cross the border are likely to result in death, it is argued. One of the warnings issued on the graveyard posters reads "Before you plan to cross the border, remember: It is hard to make a living if you lose your life", and the writing over the tombstones insinuates a number of motivations for people's failed, deadly attempts at crossing the border: "because everyone else was crossing", "because I wanted to earn some dollars" and "because they made it look easy". ${ }^{17}$ The border patrol initiative appears simply as a humanitarian effort to save lives, again as though the deadliness of unauthorized crossings was a natural fact instead of resulting from efforts to curb particular forms of migration..$^{18}$

14 Another poster motive shows a line of human figures walking through the desert at dusk, the sun casting large shadows in the direction of the viewer. While the shadow of the leader is cast in the form of a coyote, the other shadows take the shape of crosses the walking dead being led to meet their ends. "With the coyote, nothing is safe. Not even your life", the headline says. However, the results of this campaign have been far from convincing, US media outlets have reported. Mexicans who were asked to respond to the US campaigns have for the most part responded critically, and have dismissed them as far too obvious attempts to bring down the numbers of undocumented border crossings. In 2006 the American broadcasting network CNN reported on a new kind of US campaign initiative that was trying out a different strategy. The following quotation is taken from the rush transcript of the broadcast available on the CNN website: 


\begin{abstract}
Aired May 1, 2006 - 09:30 ET
M. O'BRIEN: The U.S. Border Patrol may be singing the blues as it tries to stop illegal immigrants from crossing the border, but now they are changing the music, hoping songs can stop the march. As AMERICAN MORNING's Dan Lothian tells us, it is taking the border war to a new level. And it's a story you'll see only on CNN. [...]

DAN LOTHIAN, CNN CORRESPONDENT (voice-over): The warning isn't on the label, but in the music. And the message is serious. Songs aimed at Mexicans thinking about sneaking into the U.S., a gritty, but little-known media campaign produced by the U.S. Border Patrol, which says they're airing on some 30 radio stations across Mexico.

SALVADOR ZAMORA, U.S. BORDER PATROL: They sing the very hard-hitting message: If you come across the border area, especially through the desert, you will die.

LOTHIAN: In "En La Raya", a man fleeing poverty in Mexico runs across another man barely alive in the hot desert.

LOTHIAN (on camera): The U.S. government is targeting so-called key feeder states, like Zakatekas (ph) and Chapas (ph). At first, buying the airtime for five different songs, but then, listeners began requesting the tunes, most unaware of the messenger.

ZAMORA: They don't understand, nor do they know that it is a U.S.-based government, law enforcement entity, providing this message. [...]

LOTHIAN: But the border patrol says early reports show this unique effort is getting the attention of the Mexican people.

Dan Lothian, CNN, Boston. ${ }^{19}$
\end{abstract}

This deterrence effort represents quite a different approach: the vehicle of popular culture is used both to disguise the origin of the message and to create what Roland Barthes (1957) would have called an overdetermined myth ${ }^{20}$ - a myth that links the notion of border crossing firmly to death and desperation.

Despite this imaginative way of "taking the border war to a new level", as the CNN reporter put it, it has to be questioned whether such media interventions are going to have the desired result and act as a deterrent. As in the case of potential and actual African migrants, alternative knowledge about migration routes and stories of hope and success travel in migrant support networks that span continents and national borders. Given that such knowledge and stories are generally transmitted by people connected to each other by prior relations of trust - by relatives, friends, neighbours, work colleagues, etc. - it is highly unlikely that official media campaigns will have the impact desired by their creators. Their actual significance might lie elsewhere: by contributing to a naturalization of migration-related deaths, they render it difficult to focus attention on the actual causes that prompt people to embark on dangerous journeys and border crossings. In this sense, they seamlessly tie in to the humanitarian discourses prevailing in destination countries that present migration as a journey of inevitable victimization and absorb much of the popular moral outrage in response to images of dead bodies found on tourist beaches. The same can be said for the antitrafficking discourse that aims to prevent trafficking, but does not address the causes that make trade in human beings possible, or render sex work a viable option for certain groups of migrants. ${ }^{21}$ While the United Nations definition of trafficking in human beings covers a wide range of exploitative constellations, ${ }^{22}$ it is the trafficking of women and children for purposes of sexual exploitation that forms the main focus of public campaigns. 
In May 2007 the IMO paid the advertising agency Saatchi \& Saatchi to produce what they called a "hard-hitting counter-trafficking ad" that was broadcast on BBC World, CNN and South African TV. ${ }^{23}$ Developed in cooperation with the IOM's Southern African Counter-Trafficking Assistance Programme (SACTAP), the story focused on a young African woman from a nondescript rural area who is lured by traffickers to move to South Africa with the promise of starting a modelling career. Texts appearing as graffiti on walls or in advertising spaces alerted viewers to the actual fate awaiting the woman, namely forced prostitution. Female migrants' agency, here and in other anti-trafficking campaigns, tends to be shown as compromised: whereas young migrating men are most often depicted as purposeful and determined, if light-headed, women often appear as ensnared by male evil-doers, unaware of the sexual exploitation that is in store for them. In an essay on the anti-trafficking information campaigns conducted by the IOM in Eastern Europe, Rutvica Andrijaševič has analyzed the pervasive use of images of the female body - representations that re-inscribe stereotypes of these bodies as passive objects of male violence (Andrijaševič 2007). While aimed at deterring women from deciding to migrate, these images present women as passive victims unable to make active, informed choices. The tendency to associate undocumented female migration with forced prostitution - notwithstanding the actual occurrences of forced sex trafficking that tend to involve women and children - denies informed agency to women while linking their victim status to the evil nature of male trafficking networks. ${ }^{24}$ This ignores the possibility of irregular female migrants choosing to engage in sex work as a deliberate strategy of generating income abroad, ${ }^{25}$ the multitude of other passageways and occupations sought out in their migration biographies, but also the complex nature of smuggling and informational networks that often involve extended family members, friends and acquaintances in a joint effort to overcome migration obstacles. Nieuwenhuys's and Pécoud's analysis of anti-trafficking campaigns in Eastern Europe shows how these effectively aim to discourage all forms of irregular migration, making anti-trafficking discourses a central element in the wider battle against unwanted forms of migration. ${ }^{26}$

Trafficking, however, occupies a special place not just in the deterrence campaigns described above, but also in the public discourse on irregular migration in those countries and geopolitical regions from which they were initiated. Anti-trafficking campaigns, most often directed against the trafficking of women and children for purposes of prostitution, can enlist broad support from feminist groups concerned with gender violence and from conservative social groups opposing prostitution more generally, at national and international levels. ${ }^{27}$ The EU's border security agency Frontex continuously highlights trafficking as a major problem to be tackled at the external borders of the European Union. A 2011 Frontex report compiled by its risk analysis unit entitled "Situational Overview on Trafficking in Human Beings" sidelines the evidence of trafficking in and between member states to instead focus almost exclusively on third-country trafficking into the $\mathrm{EU}$, and discusses it as a pressing security problem. All irregular migrants are presented as potential victims of trafficking, and while the victimization of women and children for the purpose of prostitution constitutes the main concern, the report also identifies men as a growing group of victims. ${ }^{28}$ Frontex public communication strategies employ a humanitarian perspective that legitimates border-control measures as lying in the best interests of irregular migrants themselves, and obfuscate the differences between trafficking and smuggling. ${ }^{29}$ This conflation between trafficking and smuggling is a common one in 
anti-trafficking discourses, ${ }^{30}$ and serves to effectively criminalize all activities that aid migrants in crossing borders without proper documentation. The focus on trafficking as a dangerous prototype of all irregular migration and the concomitant criminalization of human smuggling activities regardless of purpose or financial gain helps justify demands for stepping up the fight against irregular migration into the EU, including the deployment of new border-control technologies.

The mass-media strategies that aim for deterrence might not be particularly effective in curbing migration attempts, but they help create a climate beyond the borders of destination countries in which border-control measures appear as both necessary to "stem the floods" and as humanitarian efforts to come to the aid of irregular migrants.

The new media technologies deployed by states and agents commissioned by states to render irregular migrant bodies visible and identifiable are much less the mediator or topic of public debates, yet they nevertheless play a growing role in border-control efforts. The introduction of biometric technology in particular, which is aimed not just at irregular migrants, but deployed to facilitate regular, encouraged cross-border mobility, tends to veil processes of social sorting by presenting denials of access as instances of failed authentication, as will be discussed below. ${ }^{31}$

21 The naturalization of border-control measures is in large part produced through the introduction of new technologies that mobilize representations of migrant bodies not for purposes of communication, but for identification, authentification and control.

\title{
Non-Communicative Media Technologies in Contexts of Migration
}

\author{
In the disciplinary society populations are \\ governed in terms of sites of confinement - \\ education is experienced in terms of the \\ organized space and time of the school, \\ punishment is synonymous with the prison, work \\ with the factory, and so on. Such institutions \\ mould individuals and populations as they pass \\ from one to the next. But in control societies, \\ while we still encounter these institutions, \\ biopolitics has become much more supple, \\ dispersed and nebulous. ${ }^{32}$
}

Walters's reference to Deleuze's essay "Postscript on the Societies of Control" (Deleuze 1992) is a good starting point for thinking about the changing qualities of state power, which is increasingly exercised through technologies that allow for deterritorialized border regimes. As central dimensions of globalization, cross-border mobility and media technologies aimed at identification, authentication and control are becoming increasingly intertwined. ${ }^{33}$ Dean Wilson has suggested that in the post-9/11 climate of fear and securitization, neoliberal Western nation states invest in automated technologies of identification because they appear to promise high-tech solutions to security problems: "For the truncated nation-states of late-modernity, biometric technologies are potent signifiers of a reinvigorated sovereign power with the capacity to assert impermeable borders. ${ }^{34}$ 
23 As stated earlier in this article, it is possible to develop quite a different perspective on the links between media and migration if we go beyond the narrow definition of media as a means of communication, and take into account their role as sign technologies that allow for the construction, filtering, storage and transmission of representations for purposes of identification, information-gathering and, ultimately, control. Examples of such media include the military surveillance technology adapted to the purpose of policing virtual sea borders and entire maritime regions, such as optoelectronic sensors and radar used for the Integrado de Vigilancia Exterior (SIVE) project linking countries such as Spain, Morocco and Greece. They also include devices such as LifeGuard, a remote sensing device described by Ginette Verstraete, which reacts to the electromagnetic fields produced by beating hearts and is used in efforts to detect socalled stowaways on their way to Britain at the Belgium harbour Zeebrugge. ${ }^{35}$ Optronic surveillance technology has been implemented on Spain's southern coast and is used to scan the North African coastlines. It is similarly employed on unmanned drones flying across or swimming in the Mediterranean Sea, linked up to a satellite surveillance system in order to detect "uncooperative targets" and routes of travel. Synthetic Aperture Radar (SAR) is similarly an image-producing technology, based on microwave signals that are reflected off surfaces and objects, which can be put to use in EU bordercontrol activities regardless of weather conditions and time of day or night. ${ }^{36}$ The creation of a European Border Control System, Eurosur, envisioned by the European Commission since 2008, will extend surveillance measures to create a "common information sharing environment" that covers maritime areas from the Canary Islands to the Black Sea. ${ }^{37}$ The border surveillance infrastructure is envisioned to include neighbouring third countries. One of the main aims of maritime surveillance via satellites, unmanned aerial vehicles (UAVs) and ships is the early detection of refugee vessels in order to turn them back to their ports of origin. The technologies described above, which render irregular migrant bodies visible in their efforts to cross borders unnoticed, complement those that are deployed at official border-crossing sites to authenticate the identity of mobile bodies and to grant or deny entry or passage.

In February 2013 the European Commission announced that it was to begin negotiations with the European Parliament and the Council on its "smart border package", aiming to use biometric technologies in order to control both entry and exit for third-country citizens and to facilitate travel for some of them. ${ }^{38}$ In light of the findings that the majority of irregular migrants in EU member states had overstayed their visas rather than entered the EU without authorizing documentation, the collection of biometric data and the tracing of exits as well as entries is deemed both necessary and expedient, despite the huge financial costs.

Biometrical information that is increasingly used in passports and ID cards to facilitate and intensify mobility control at and beyond border crossings, is based on semiotic technologies, insofar as particular properties of bodies are stored and used to generate representational profiles that can be constructed to identify individuals. These semiotic technologies, however, are not implemented for communicative purposes but for those of social sorting and identification. As technologies of identification, social sorting and control, their uses extend far beyond the regulation of cross-border mobilities. Irma van der Ploeg has noted that biometric identification is primarily aimed at marginal social groups such as suspected and convicted criminals, welfare recipients and migrants. ${ }^{39}$ The deployment of biometric information also extends, however, to 
apparently innocuous uses, such as fingerprinting to protect access to mobile phones and laptops, and promises additional security in new media environments where identity theft and online fraud are on a steep increase.

Media technologies involving biometrics are central to building up databases such as the Schengen Information System (SIS) that now links most member states. The SIS represents a new stage in storing and linking different types of information that allow for biometrical profiling and quick identification of individuals across the EU. The Eurodac database, which began operating in 2003 to identify asylum seekers across EU countries, digitizes and stores the fingerprints not just of asylum seekers but of any third-country national who tries to or has already entered a member state without the required authorization (Wilson 2006: 101). ${ }^{40}$ Irma van der Ploeg delivered a powerful argument for considering the Eurodac biometrics as a form of sign technology when she argued "... we see bodies being marked with a sign that can be read by the appropriated equipment wherever these bodies go" and challenged that this created a new form of stigma - "signs on the flesh". ${ }^{41}$

As EU border functions become increasingly distanced from the territorial frontiers of member states - such as when airlines are held responsible for checking visas in countries of departure or passage, when boats carrying irregular migrants are turned away in international waters, when ID checks can be carried out anywhere "inside" EU countries (at major train stations, etc.) - such technologies become ever more central for purposes of control and surveillance. ${ }^{42}$ Encampments, border control and deportation measures at first sight do not seem to involve media technologies in any obvious way, but the politics of border deterritorialization and increasing control of mobility do in fact involve them at several levels, as has been shown. These "postmodern" practices of statehood are much more difficult to scandalize than the erecting of fences and high walls when it comes to border control. In a political climate focused on alleged security threats, particularly in relation to terrorism, optical surveillance technologies such as CCTV but also biometrical data-processing is presented as a panacea to minimize risk. ${ }^{43}$ What is more, biometric ID systems promise to simultaneously ease the mobility of those elite parts of populations whose transnational mobility is globally encouraged rather than curtailed, mostly in the interest of promoting global trade relations. ${ }^{44}$

To give an example, the US-VISIT programme that was announced by the Department of Homeland Security in the spring of 2003 gathers biometrical information on all foreign-passport visitors, in order to both prevent the entry of persons deemed a security risk and, in combination with 'fast lane' programmes, to speed up the processing of visitors deemed harmless/desirable. ${ }^{45}$ Biometrical information on individuals is also coupled with risk assessment based upon group membership: nationality, gender, religion and age, but also previous travel histories, phone records and credit card purchases, are combined on the basis of intelligence information in order to determine levels of "terrorist threat", with the consequence of subjecting those deemed to present a potential threat to more extensive data-gathering, questioning and registration procedures long before they have actually reached the territorial border. ${ }^{46}$ The governing of risk through the biometric border, Louise Amoore has argued, is “... based on dividing practices that segregate 'legitimate' mobilities (business, travel, leisure and so on) from 'illegitimate' (terrorist, trafficker, immigrant and so on)" ${ }^{47}$ To engage in this form of sorting, "risk profiles" are established that, in 
the words of a critic, ${ }^{48}$ ".... are assumed to provide a complete picture of who someone is, leaving people having to dispute their own identity". ${ }^{49}$ Mediated representation in the context of risk profiling creates identities that are difficult to shed. The body, Amoore suggests, becomes itself the carrier of the border as it contains the codes for being granted or denied access. The problematic consequences with regard to curtailing civil liberties, stigmatizing particular groups and subjecting them to unequal treatment are obvious.

\section{Conclusion}

While there is by now significant academic and even wider public sensitivity toward the mass-mediated production of images and other signs representing migrants and migration processes in public discourses, the state- and supra-state-driven uses of media and information technologies for purposes of migration and mobility control have received much less critical attention. This also holds true for the sociology of migration and migration studies as an interdisciplinary field of inquiry, which has yet to integrate the insights of the relatively recent 'mobilities' turn ${ }^{50}$ and the emergent field of surveillance studies. ${ }^{51}$ In light of contemporary developments, however, it seems of paramount importance to focus on the consequences and contexts of these uses, and to connect them back to public debates concerning media representations of migrants and migration.

Several challenges mitigate against this linkage, some of which have already been addressed above: as the risks of clandestine migration are naturalized - the waywardness of the sea, the difficulties of navigating small boats on the ocean - the state measures that are employed to force would-be migrants into taking ever greater risks are rendered invisible. Secondly, the climate of fear regarding terrorism in the context of the so-called war on terror contributes to the acceptance of state measures that curtail civil liberties and institutionalize surveillance measures in the interest of "security". Thirdly, biometrical information that is used to identify individuals appears unproblematic to many citizens of the global North, including third-country citizens and elites from the global South, who think that they have nothing to hide from state authorities, and even partly stand to gain by speeding up travel, monetary transactions, access to restricted areas, and not least the alleged protection against acts of terrorism. However, the coupling of biometrical information with risk profiling based on categorical membership ascription - such as the Muslim male national of Yemen who has to register each change of address or place of work within the United States according to the US-Visit programme - allows for entire groups to be declared suspect, and opens the door toward a plethora of (ab)uses that mobilize multiple socially and politically relevant axes of inequality and diversity for various means.

31 Rendering these (ab)uses visible and making them the subject of discussion is made difficult by the seemingly innocuous and neutral character of the technologies deployed, in stark contrast to the barbed wire and high fences traditionally associated with fortified, territorial state borders. Digitalized fingerprinting and iris-scans take less than a minute to produce, yet can be stored and processed for different purposes of social sorting, identification and exclusion. Once transformed into algorithms and made part of larger databases, their potential for purposes of surveillance and tracking is difficult to curtail. ${ }^{52}$ What is more, biometric technologies merge seamlessly with 
contemporary consumer practices and the "death of anonymity" in online social networks, transforming our understandings of privacy and what we are willing to reveal about our personal lives. ${ }^{53}$

What, then, is the link between the uses of media intended for communicative purposes that depict irregular migration as a life-threatening undertaking and criminal act, and the non-communicative technologies that aim to detect bodies and compile risk profiles for the purposes of identification, surveillance and control? Is the former just a smokescreen to hide the much more drastic effects of the latter, keeping NGOs, critical media and migration scholars busy while the real work of controlling borders happens elsewhere?

Two avenues for thinking about those linkages, as speculative as they might be, seem worthy of pursuing. The first is considering the outreach efforts in the context of media campaigns to deter potential irregular migrants from embarking upon border crossings as indicative of the limits of surveillance, however sophisticated the technologies deployed. It is important to remember that the promise of total control over access to the territory of sovereign nation states or supra-national entities such as the EU is, at least for now, part fiction. As boats with undocumented, paperless refugees whose bodily markers have not yet been stored in the respective databases continue to reach the Mediterranean shorelines of EU member states such as Greece, Spain or Italy, the difficulties of creating an impenetrable "Fortress Europe" become evident. ${ }^{54}$ From a perspective of deterrence, outreach work thus still makes sense.

The second linkage concerns the focus on trafficking in mass-mediated public campaigns that often bridge "sending" and destination countries, as has been discussed above. Two conflations, it has been shown, help to create public perceptions and media representations of irregular migration that depict it as criminal and morally depraved. The first is the slippage between concepts of human smuggling and trafficking, which affiliates smuggling with forms of exploitation, and the second the equation of trafficking with sex trafficking, in particular the sexual exploitation of women and children. A broad political, transnational alliance against trafficking contributes to a political climate, particularly in destination countries, in which calls for stricter punishment and border surveillance legitimate the introduction of new technologies for border control. While the empirical effects of this introduction might entail an ever growing dependence of irregular migrants on sophisticated smuggling networks, this introduction can nevertheless, as has been shown for Frontex, be passed off as being in the best interest of "victimized" irregular migrants themselves, while combatting immoral crime networks. In the context of the EU in particular, the scandalization of trafficking, particularly sex trafficking, helps to prepare the ground for an extension of securitization and justification for biometric technologies. In the context of the USA, the alleged security failures that led up to the terror attacks of $9 / 11$ provided an even stronger legitimation and motivation for investing in biometric technologies of identification and risk management.

The conjuncture of biometrics, which tends to conceal the discriminatory practices that lie behind the seemingly neutral concern with identification and authentication, with the discursive shift toward criminalizing and scandalizing unwanted forms of migration and border crossing, most starkly visible in the trafficking debates, thus produces new, disconcerting modes of regulating cross-border movement that have wide implications beyond issues of migration and mobility. Biometric technologies can 
be and are expanded from migration management to other regimes of access and mobility control..$^{55}$

As stated, the technologies of control and modulation that Deleuze (1992) diagnosed to succeed Foucault's disciplinary societies, which operated with technologies of enclosure, are difficult to scandalize, and even to depict in their operations. It is in fictional accounts that the consequences and dangers of new media/information technologies and their impact on migrants as well as minorities have been best described so far. The work of David Lyon includes numerous references to the Hollywood blockbuster Minority Report and the film trilogy The Matrix, showing biometric dystopias in which borders have multiplied to all dimensions of daily life. Louise Amoore points to artistic interventions as an important form of dissent, discussing the work of British artist Heath Bunting. ${ }^{56}$

In the European context, the short film Schenglet (by Laurent Nègre 2002) fictionalizes the operation of a visa-bracelet constructed for use by third-country nationals visiting the European Union. Presented in the aesthetic mould of an airplane safety instruction and advertising commercial, the electronic bracelet is attached to visitors' arms and serves as both visa, identity document and personal information tool designed to facilitate the traveller's sojourn in the Schengen Zone. It is only when the visitors overstay their designated visitation period that the bracelet reveals its dangerous and punitive aspects, at first emitting an alarm signal before later on injecting subduing substances into the carrier's blood system while imprinting a signature that will prevent re-entry into the Schengen Zone in the future. While Schenglet is deeply ironic in its parody of border-control measures, the realities of smart border development seem to lag not far behind: the US Department of Homeland Security is experimenting with radio frequency identification to be embedded in ID documents that would allow not only for border controls in the vicinity of border checkpoints, but for the remote tracking of carrying individuals.

\section{BIBLIOGRAPHY}

\section{Literature}

Amoore, Louise. "Biometric borders: Governing Mobilities in the War on Terror." Political Geography 25(3) (2006): 336-351.

Andreas, Peter. Border Games: Policing the U.S.-Mexico Divide. Ithaca: Cornell University Press, 2000.

Augustín, Laura. "Migrants in the Mistress's House: Other Voices in the 'Trafficking' Debate."

Social Politics 12(1) (2005): 96-117.

Barthes, Roland. Mythologies. Paris: Le Seuil, 1957.

Bauman, Zygmunt, and David Lyon. Liquid Surveillance. Cambridge: Polity Press, 2013. 
Bernstein, Elizabeth. "Militarized Humanitarianism Meets Carceral Feminism: The Politics of Sex, Rights, and Freedom in Contemporary Antitrafficking Campaigns.” Signs 36(1) (2010): 45-71.

Castells, Manuel. The Information Age: Economy, Society and Culture, Vol. I.3. Cambridge, MA/Oxford, UK: Blackwell, 1993.

Chacón, Jennifer. "Misery and Myopia: Understanding the Failures of U.S. Efforts to Stop Human Trafficking.” Fordham Law Review 74(6) (2006): 2977-3040.

Cresswell, Tim. On the Move: Mobility in the Modern Western World. London: Routledge, 2006.

Deleuze, Gilles. "Postscript on the Societies of Control." October 59 (1992): 3-7.

Dietrich, Helmut. "Das Mittelmeer als neuer Raum der Abschreckung“, Forschungszentrum Flucht und Migration, 2005. Accessed 3 September 3 2014. http://www.ffm-berlin.de/ mittelmeer.html.

Fuller, Gillian. "Perfect Match: Biometrics and Body Patterning in a Networked World." The Fibreculture Journal 01 FCJ-002, (2003). http://one.fibreculturejournal.org./fcj002.

Georgiou, Myria. Diaspora, Identity and the Media. Cresskill, NJ: Hampton Press, 2006.

Hayes, Ben, and Mathias Vermeulen. Borderline. The EU's new Border Surveillance Initiatives. Berlin: Heinrich Böll Foundation, 2012.

Hess, Sabine, and Bernd Kasparek, eds. Grenzregime : Diskurse, Praktiken, Institutionen in Europa. Berlin: Assoziation A, 2010.

Horst, Heather. "The Blessings and Burdens of Communication: Cell Phones in Jamaican Transnational Social Fields." Global Networks 6(2) (2006): 143-159.

Horsti, Karina. "Humanitarian Discourse Legitimating Migration Control: FRONTEX Public Communication." In Migrations: Interdisciplinary Perspectives, edited by Michi Messer, Renée Schroeder and Ruth Wodak, 297-308. Vienna: Springer-Verlag, 2012.

Husband, Charles. "Minority Ethnic Media as Communities of Practice: Professionalism and Identity Politics Interaction.” Journal of Ethnic and Migration Studies 31(3) (2005): 461-479.

Jenkins, Henry. Convergence Culture: Where Old and New Media Collide. New York: New York University Press, 2006.

Kaczynski, Vlad M. and David L. Fluharty. "European Policies in West Africa: Who Benefits from Fisheries Agreements?” Marine Policy 26(2) (2002): 75-93.

Kane, Linda. "Border Safety Initiative: A Multi-Faceted Approach to Enhancing Border Safety", Customs and Border Protection TODAY (2004). Accessed on 3 September 2009. http://www.cbp.gov/ $\mathrm{xp} /$ CustomsToday/2004/June/bsi_falfurrias.xml.

Koslowski, Rey. "Information Technology, Migration and Border Control”. Paper prepared for presentation at the Institute for Government Studies, University of California, Berkeley, April 25, 2002.

Kosnick, Kira. Migrant Media: Turkish Broadcasting and Multicultural Politics in Berlin. Bloomington: Indiana University Press, 2007.

Lash, Scott M., and John Urry. "Economies of Signs and Space.” Contemporary Sociology 23(6) (1994): 838-840.

Lyon, David. "Surveillance Studies: Understanding Visibility, Mobility and the Phonetic Fix." Surveillance \& Society 1(1) (2002a): 1-7. 
- ed. Surveillance as Social Sorting: Privacy, Risk and Digital Discrimination. London: Routledge, 2002b.

-. Surveillance Studies: An Overview. Cambridge: Polity Press, 2007.

Madianou, Mirca, and Daniel Miller. Migration and New Media: Transnational Families and Polymedia. New York: Routledge, 2012.

Miller, Daniel, and Don Slater. The Internet: An Ethnographic Approach. Oxford and New York: Berg, 2000.

Müller, Daniela. "Die Entwicklung des Sicherheitsdiskurses im Kontext des europäischen Grenzund Migrationsregimes am Beispiel von Frontex." Unpublished MA thesis, Department of Sociology, Goethe University Frankfurt, 2014.

Muller, Benjamin J. “(Dis)Qualified Bodies: Securitization, Citizenship, and Identity Management.” Citizenship Studies 8(3) (2004): 279-294.

Nieuwenhuys, Céline, and Antoine Pécoud. "Human Trafficking, Information Campaigns, and Strategies of Migration Control." American Behavioural Scientist 50(12) (2007): 1674-1695.

Rigoni, Isabelle. “Éditorial : Les médias des minorités ethniques. Représenter l'identité collective sur la scène publique." Revue européenne des migrations internationales 26(1) (2010): 7-16.

Salter, Mark B. "Passports, Mobility, and Security: How Smart Can the Border Be?" International Studies Perspectives 5 (2004): 71-91.

Shah, Svati. "South Asian Border Crossings and Sex Work: Revisiting the Question of Migration in Anti-Trafficking Interventions." Sexuality Research and Social Policy 5(4) (2008): 19-30.

Sheller, Mimi. “Air-Mobilities on the U.S.-Caribbean Border: Open Skies and Closed Gates." The Communication Review 13(4) (2010): 269-288.

-. "Mobility." In Sociopedia.isa 2011. Accessed on 16 March 2014. http://www.sagepub.net/isa/ resources/pdf/Mobility.pdf.

Sheller, Mimi, and John Urry. “The New Mobilities Paradigm.” Environment and Planning A 38(2) (2006): 207-226.

Shohat, Ella, and Robert Stam. Unthinking Eurocentrism: Multiculturalism and the Media. London: Routledge, 1994.

Sreberny, Annabelle. "The Role of the Media in the Cultural Practices of Diasporic Communities." In Differing Diversities: Transversal Study on the Theme of Cultural Policy and Cultural Diversity, edited by T. Bennett, 155-167. Strasbourg: Council of Europe Publishing, 2001.

Stolcke, Verena. “Talking Culture: New Boundaries, New Rhetorics of Exclusion in Europe." Current Anthropology 36(1) (1995): 1-24.

Thainiyom, Prawit. "A Media Campaign to Increase Awareness and Prevention of Human Trafficking in Asia: Background Strategies and Outcome Evaluation of the MTV EXIT Campaign", Third Annual Interdisciplinary Conference on Human Trafficking, 2011. Paper 17. Accessed on March 15, 2014. http://digitalcommons.unl.edu/humtraffconf3/17.

Thompson, Eric. "Mobile Phones, Communities and Social Networks among Foreign Workers in Singapore." Global Networks 9(3) (2009): 359-380.

Transit Migration Forschungsgruppe. Turbulente Ränder. Neue Perspektiven auf Migration an den Grenzen Europas. Bielefeld: Transcript Verlag, 2007. 
Van der Ploeg, Irma. “The Illegal Body: 'Eurodac' and the Politics of Biometric Identification.” Ethics and Information Technology 1(4), (1999): 295-302.

Verstraete, Ginette. "Technological Frontiers and the Politics of Mobility in the European Union." In Uprootings/Regroundings: Questions of Home and Migration, edited by Ahmed et al., 225-249. Oxford: Berg Publishers, 2003.

-. Tracking Europe: Mobility, Diaspora, and the Politics of Location. Durham: Duke, 2010.

Waller Meyers, Deborah. “Does 'Smarter' Lead to Safer? An Assessment of the US Border Accords with Canada and Mexico.” International Migration 41(4) (2003): 5-44.

Walters, William. “Mapping Schengenland: Denaturalizing the Border." Environment \& Planning D: Society \& Space 20(5) (2002): 561-80.

Weitzer, Ronald. "The Social Construction of Sex Trafficking: Ideology and Institutionalization of a Moral Crusade." Politics \& Society 35(3) (2007): 446-475.

Wilding, Raelene. "'Virtual' intimacies? Families Communicating across Transnational Contexts." Global Networks 6(2) (2006): 125-142.

Wilson, Dean. "Biometrics, Borders and the Ideal Suspect." In Borders, Mobility and Technologies of Control, edited by Sharon Pickering and Lisa Weber, 87-109. Dordrecht: Springer, 2006.

Zureik, Elia, and Mark B. Salter eds. Global Surveillance and Policing. Cullompton and Portland: Willan Publishing, 2005.

\section{Weblinks}

http://www.washingtonpost.com/wp-dyn/content/article/2009/03/13/AR2009031304234.html, posted 15 March 2009.

http://news.bbc.co.uk/player/nol/newsid_7000000/newsid_7003900/7003961.stm?

$\mathrm{bw}=\mathrm{bb} \& \mathrm{mp}=\mathrm{wm} \& \mathrm{asb}=1 \&$ news $=1$

http://www.iom.int/jahia/Jahia/pbnAF/cache/offonce?entryId=14192\&titleHolder=HardHitting\%20Counter-Trafficking\%20Ad\%20Hits\%20TV\%20Screens\%20in\%20South\%20Africa

http://transcripts.cnn.com/TRANSCRIPTS/0605/01/ltm.05.html

http://southport.jpl.nasa.gov/desc/imagingradarv3.html

http://ec.europa.eu/enterprise/newsroom/cf/document.cfm?

action=display\&doc_id=5045\&userservice_id $=1 \&$ request.id=0

http://www.blick.ch/news/ausland/so-schrecken-wir-die-afrikaner-ab-76915

http://www.schenglet.org/

http://europa.eu/rapid/press-release_IP-13-162_en.htm

\section{ENDNOTES}

1. Myria Georgiou, Diaspora, Identity and the Media (Cresskill, NJ: Hampton Press, 2006); Charles Husband, "Minority Ethnic Media as Communities of Practice: Professionalism and Identity Politics Interaction," Journal of Ethnic and Migration Studies 31(3) (2005); Kira Kosnick, Migrant Media: Turkish Broadcasting and Multicultural Politics in Berlin (Bloomington: Indiana University 
Press, 2007); Daniel Miller, and Don Slater, The Internet: An Ethnographic Approach (Oxford and New York: Berg, 2000); Isabelle Rigoni, "Éditorial : Les médias des minorités ethniques. Représenter l'identité collective sur la scène publique," Revue européenne des migrations internationales 26(1) (2010); Annabelle Sreberny, "The Role of the Media in the Cultural Practices of Diasporic Communities," in Differing Diversities: Transversal Study on the Theme of Cultural Policy and Cultural Diversity, ed. T. Bennett (Strasbourg: Council of Europe Publishing, 2001).

2. Henry Jenkins, Convergence Culture: Where Old and New Media Collide (New York: New York University Press, 2006).

3. Scott M. Lash, and John Urry, "Economies of Signs and Space," Contemporary Sociology 23(6) (1994).

4. Manuel Castells, The Information Age: Economy, Society and Culture, Vol. I.3 (Cambridge, MA/ Oxford, UK: Blackwell, 1993).

5. Heather Horst, "The Blessings and Burdens of Communication: Cell Phones in Jamaican Transnational Social Fields," Global Networks 6(2) (2006); Mirca Madianou, and Daniel Miller, Migration and New Media: Transnational Families and Polymedia (New York: Routledge, 2012); Eric Thompson, "Mobile Phones, Communities and Social Networks among Foreign Workers in Singapore," Global Networks 9(3) (2009); Raelene Wilding, “Virtual' intimacies? Families Communicating across Transnational Contexts," Global Networks 6(2) (2006).

6. William Walters, "Mapping Schengenland: Denaturalizing the Border," Environment \& Planning D: Society \& Space 20(5) (2002).

7. Sabine Hess, and Bernd Kasparek, eds, Grenzregime : Diskurse, Praktiken, Institutionen in Europa (Berlin: Assoziation A, 2010).

8. Privatization is also importantly taking shape in the form of commercialization, with airline carriers paid to "repatriate" unwanted migrants, and security firms as well as surveillance technology developers benefiting from the new forms of migration and cross-border mobility management (see Verstraete 2003, 2010).

9. Helmut Dietrich, "Das Mittelmeer als neuer Raum der Abschreckung," Forschungszentrum Flucht und Migration, 2005, accessed 3 September 2014, http://www.ffm-berlin.de/ mittelmeer.html.

10. Ibid.

11. Verena Stolcke, "Talking Culture: New Boundaries, New Rhetorics of Exclusion in Europe," Current Anthropology 36(1) (1995).

12. Céline Nieuwenhuys, and Antoine Pécoud, "Human Trafficking, Information Campaigns, and Strategies of Migration Control." American Behavioural Scientist 50(12) (2007).

13. http://goo.gl/o4UlGH.

14. http://afp.google.com/article/ALeqM5hApDQmvzPigjqkh38XUPrSFi7E3g.

15. Vlad M. Kaczynski, and David L. Fluharty, "European Policies in West Africa: Who Benefits from Fisheries Agreements?" Marine Policy 26(2) (2002).

16. See the campaign at http://www.nomascruces.org/, accessed 08 October 214.

17. Linda Kane, "Border Safety Initiative: A Multi-Faceted Approach to Enhancing Border Safety," Customs and Border Protection TODAY (2004), accessed 3 September, 2009, http://www.cbp.gov/xp/ CustomsToday/2004/June/bsi_falfurrias.xml.

18. For a careful analysis of US border politics along the border with Mexico, see Andreas 2000.

19. CNN, accessed 19 March 2014, http://transcripts.cnn.com/TRANSCRIPTS/0605/01/ltm. 05.html.

20. Roland Barthes, Mythologies (Paris: Le Seuil, 1957).

21. Another example of a large-scale, mass-mediated awareness campaign that focused on human trafficking (and not necessarily border crossing) was conducted in Asia in 2006: the MTV EXIT Campaign was launched across different media formats by USAID and the broadcaster MTV. A study sought to evaluate its impact in terms of awareness levels in different countries. The data 
presented does not allow for authoritative conclusions to be drawn regarding its effects (see Thainiyom 2011).

22. See https://www.unodc.org/unodc/en/human-trafficking/what-is-human-trafficking.html? ref=menuside\#What_is_Human_Trafficking

23. See http://www.iom.int/jahia/Jahia/pbnAF/cache/offonce?entryId=14192\&titleHolder=HardHitting\%20Counter-Trafficking\%20Ad\%20Hits\%20TV\%20Screens\%20in\%20South\%20Africa

24. Ronald Weitzer, "The Social Construction of Sex Trafficking: Ideology and Institutionalization of a Moral Crusade," Politics \& Society 35(3) (2007).

25. Laura Augustín, "Migrants in the Mistress's House: Other Voices in the 'Trafficking' Debate." Social Politics 12(1) (2005).

26. Nieuwenhuys and Pécoud, 2007.

27. Ronald Weitzer, 2007; Elizabeth Bernstein, "Militarized Humanitarianism Meets Carceral Feminism: The Politics of Sex, Rights, and Freedom in Contemporary Antitrafficking Campaigns," Signs 36(1) (2010); Svati Shah, "South Asian Border Crossings and Sex Work: Revisiting the Question of Migration in Anti-Trafficking Interventions," Sexuality Research and Social Policy 5(4) (2008).

28. Daniela Müller, "Die Entwicklung des Sicherheitsdiskurses im Kontext des europäischen Grenz- und Migrationsregimes am Beispiel von Frontex." Unpublished MA thesis, Department of Sociology: Goethe University Frankfurt, 2014: 79.

29. Karina Horsti, "Humanitarian Discourse Legitimating Migration Control: Frontex Public Communication," in Migrations: Interdisciplinary Perspectives, ed. Michi Messer, Renée Schroeder and Ruth Wodak (Vienna: Springer-Verlag, 2012).

30. Jennifer Chacón, "Misery and Myopia: Understanding the Failures of U.S. Efforts to Stop Human Trafficking," Fordham Law Review 74(6) (2006).

31. David Lyon, ed., Surveillance as Social Sorting: Privacy, Risk and Digital Discrimination (London: Routledge, 2002b).

32. Walters, "Mapping Schengenland".

33. Rey Koslowski, "Information Technology, Migration and Border Control." Paper prepared for presentation at the Institute for Government Studies, University of California, Berkeley, April 25, 2002.

34. Dean Wilson, "Biometrics, Borders and the Ideal Suspect," in Borders, Mobility and Technologies of Control, ed. Sharon Pickering and Lisa Weber (Dordrecht: Springer, 2006), 94.

35. Ginette Verstraete, "Technological Frontiers and the Politics of Mobility in the European Union," in Uprootings/Regroundings: Questions of Home and Migration, ed. Ahmed et al. (Oxford: Berg Publishers, 2003).

36. As presented at a UAV information workshop in Brussels on 10 November 2008, http:// ec.europa.eu/enterprise/newsroom/cf/document.cfm?

action=display\&doc_id=5045\&userservice_id=1\&request.id=0. For information on SAR, see http:// southport.jpl.nasa.gov/desc/imagingradarv3.html. Both accessed 15 June 2010.

37. Ben Hayes, and Mathias Vermeulen, Borderline. The EU's new Border Surveillance Initiatives (Berlin: Heinrich Böll Foundation, 2012).

38. http://europa.eu/rapid/press-release_IP-13-162_en.htm, accessed 16 March 2014.

39. Irma Van der Ploeg, "The Illegal Body: 'Eurodac' and the Politics of Biometric Identification," Ethics and Information Technology 1(4), (1999).

40. Dean Wilson, "Biometrics, Borders and the Ideal Suspect," in Borders, Mobility and Technologies of Control, ed. Sharon Pickering and Lisa Weber (Dordrecht: Springer, 2006): 101.

41. Van der Ploeg, "The Illegal Body”, 301.

42. Elia Zureik, and Mark B. Salter, eds, Global Surveillance and Policing (Cullompton and Portland: Willan Publishing, 2005). 
43. Benjamin J. Muller, "(Dis)Qualified Bodies: Securitization, Citizenship, and Identity Management," Citizenship Studies 8(3) (2004).

44. Ginette Verstraete, Tracking Europe: Mobility, Diaspora, and the Politics of Location (Durham: Duke, 2010).

45. Louise Amoore, "Biometric borders: Governing Mobilities in the War on Terror," Political Geography 25(3) (2006); Deborah Waller Meyers, "Does 'Smarter' Lead to Safer? An Assessment of the US Border Accords with Canada and Mexico," International Migration 41(4) (2003).

46. Mark B. Salter, "Passports, Mobility, and Security: How Smart Can the Border Be?" International Studies Perspectives 5 (2004).

47. Amoore, "Biometric borders", 339.

48. A lawyer interviewed by Amoore who works for the Electronic Privacy Information Center (EPIC).

49. Amoore "Biometric borders", 340.

50. Tim Cresswell, On the Move: Mobility in the Modern Western World (London: Routledge, 2006); Mimi Sheller, "Air-Mobilities on the U.S.-Caribbean Border: Open Skies and Closed Gates," The Communication Review 13(4) (2010); Mimi Sheller, and John Urry, "The New Mobilities Paradigm," Environment and Planning A 38(2) (2006).

51. David Lyon, "Surveillance Studies: Understanding Visibility, Mobility and the Phonetic Fix," Surveillance \& Society 1(1) (2002a); David Lyon, ed., Surveillance as Social Sorting: Privacy, Risk and Digital Discrimination (London: Routledge, 2002b); David Lyon, Surveillance Studies: An Overview (Cambridge: Polity Press, 2007).

52. Dean Wilson, "Biometrics, Borders and the Ideal Suspect," in Borders, Mobility and Technologies of Control, ed. Sharon Pickering and Lisa Weber (Dordrecht: Springer, 2006).

53. In fact, the lack of public outcry over the Edward Snowden revelations can be understood only in this context, and at the same time demonstrates the dangerous complacency produced by the normalization of what Bauman and Lyon call "liquid surveillance" in Western democratic nation states. See Zygmunt Bauman, and David Lyon, Liquid Surveillance (Cambridge: Polity Press, 2013).

54. Transit Migration Forschungsgruppe, Turbulente Ränder. Neue Perspektiven auf Migration an den Grenzen Europas (Bielefeld: Transcript Verlag, 2007).

55. Bauman and Lyon, Liquid Surveillance.

56. Amoore, "Biometric borders".

\section{ABSTRACTS}

This article aims to expand the scope of studying media in relation to migration and diversity by addressing new forms of media deployment in the interest of regulating migration flows to the European Union and the United States. Beyond constructing representations of minorities and migration processes that impact interethnic relations and politics in countries of immigration, it is argued that media technologies and representations have new roles to play when it comes to targeting potential migrants to prevent mobility across borders, both in the sense of addressing them as audiences in order to discourage migration, and in the sense of non-communicative technologies that provide data in order to engage in social sorting and identification for the purposes of mobility control and surveillance.

\section{INDEX}

Mots-clés: migration, borders, biometrics, EU, United States 


\section{AUTHOR}

\section{KIRA KOSNICK}

Kira Kosnick is professor of sociology at Goethe University Frankfurt. After obtaining her Ph.D. in cultural anthropology from the New School for Social Research in the United States, she worked as lecturer in cultural analysis at Nottingham Trent University in England. She joined the Department for Cultural Anthropology and European Ethnology at Goethe University Frankfurt in 2006, before moving to her current post in the Department of Sociology in 2010. Her work focuses on transnational migration, migrant media production, urban public space and cultural theory, with a regional focus on Germany and Turkey. She recently conducted an ERC Starting Grant Project entitled “New Migrant Socialities: Ethnic Club Cultures in Urban Europe”. During the academic year 2013/14, she held a post as DAAD Distinguished Professor of German and European Studies at the Munk School of Global Affairs at the University of Toronto. 